\title{
Neotypification of Abutilon neelgerrense (Malvaceae)
}

\author{
V.V. Nimbalkar ${ }^{1}$, G.M. Tambde ${ }^{1}$, K.M. Prabhukumar ${ }^{2}$ and M.M. Sardesai ${ }^{3 *}$ \\ 'Department of Botany, Dr. Babasaheb Ambedkar Marathwada University, Aurangabad, \\ Maharashtra - 431 004, India. \\ ${ }^{2}$ Centre for Medicinal Plants Research, Arya Vaidya Sala, Kottakkal (P.O.), Kerala - 676 503, India. \\ ${ }^{3}$ Department of Botany, Savitribai Phule Pune University, Pune, Maharashtra - 411 007, India. \\ *Email: sardesaimm@gmail.com
}

\begin{abstract}
Critical examination of protologue, literature and herbarium consultation could not trace the original material of endemic Indian species, Abutilon neelgerrense Munro ex Wight. Therefore, the name is neotypified here.
\end{abstract}

Keywords: Endemic, Orthographic variants, Taxonomy, Typification.

\section{Introduction}

Abutilon Mill. is one of the five largest genera of the subfamily Malvoideae (tribe Malveae) of Malvaceae comprises c. 120 tropical and subtropical species (Mabberley, 2017). In India, 12 species are reported so far (Paul, 1993), of which seven are recorded from southern parts of peninsular India (Sivarajan \& Pradeep, 1996). As a part of the ongoing taxonomic revision on the genus Abutilon in India, the need for neotypification of the name Abutilon neelgerrense Munro ex Wight was identified. The neotype is designated here according to Art. 9.8 of the ICN (Turland et al., 2018). The paper also discusses the discrepancies in the usage of spelling of specific epithet in literature.

\section{Typification}

Abutilon neelgerrense Munro ex Wight, Ill. Ind. Bot. 1(1-8): 66. 1838.

Neotype (designated here): INDIA, Andhra Pradesh, Horsley hills, $13^{0} 38^{\prime} 45.2^{\prime \prime}$ N, 78 24'31.6" E, 1105 m, 25.12.2017, Nimbalkar 601 (CAL; Isoneotypes, BAMU, BSI, BLAT, MH).

Fig. 1.

Munro proposed the name Abutilon neelgerrense based on his collections from Nilgiri mountains in an unpublished manuscript. Later Wight (1838) validated this name based on Munro's unpublished manuscript and collections. According to Stafleu and Cowan (1981), Munro's herbarium and types have been housed at $K$, and further material at DD, E, GRA, and OXF. Our efforts to trace out the specimens in any of these herbaria are in vain. During the revision of the family Malvaceae in peninsular India, Sivarajan and Pradeep (1996) mentioned about its type as "Neelgherris, Munro s.n. (K)". However, Noltie (2005) in his book, "The Botany of Robert Wight" stated that "No specimens at K or E". Furthermore, on request Dr. Sally Dawson, Senior Curator-Botanist, at Royal Botanic Gardens, Kew have checked the holdings at K, and informed us that there is no extant of specimens in the name 'Abutilon neelgerrense'(or 'neilgherrense'). It is confirmed that no original material referred to A. neelgerrense is extant at present and it warrants the need of neotypification. According to Art. 9.8 of ICN (Turland et al., 2018) one of our collections (Nimbalkar 601) of A. neelgerrense, which bears flowers, fruits and perfectly matching with the protologue is chosen as neotype and duplicates of the same as isoneotypes.

During the present study it was also noted that there are discrepancies in the usage of spelling of specific epithet in the publications of subsequent researchers. In the protologue specific epithet is spelled as 'neelgerrense' whereas subsequent workers used 'neilgherrense' (Masters, 1874; Dunn, 1915; Chandrabose et al., 1979, Chandrabose, 1983; Saldanha \& Ramesh, 1984; Paul \& Nayar, 1988; Paul, 1993; Pullaiah \& Rao, 2002; Sasidharan, 2004, 2013; Mohanan \& Rao, 2005) except Sivarajan \& Pradeep (1996) and Noltie (2005). Moreover, online databases (www.ipni.org; www. tropicos.org; www.theplantlist.org) also used another orthographic variant of specific epithet, 'neelgherrense'. However, according to Art. 60.1 of ICN (Turland et al., 2018), original spelling of name or epithet is to be retained and hence it is suggested to use the original spelling of specific epithet 'neelgerrense' as used by original author in the protologue which is properly Latinized and decline with neuter gender of genus Abutilon. 


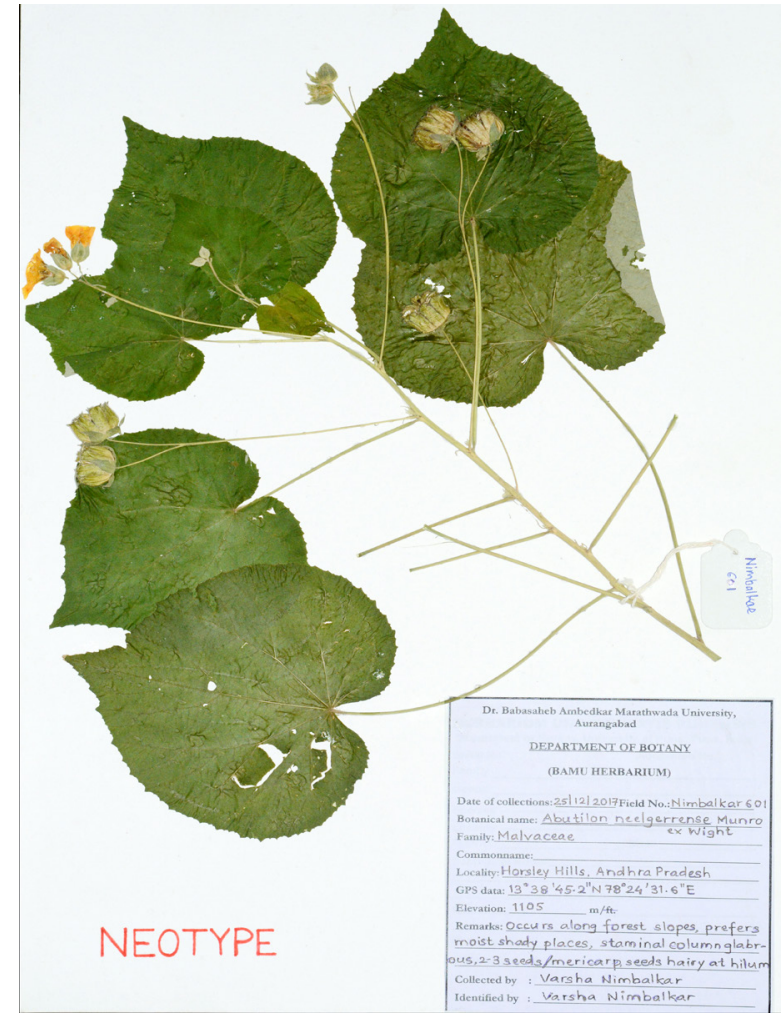

Fig.1. Neotype of Abutilon neelgerrense Munro ex Wight (Nimbalkar $601, \mathrm{CAL})$.

\section{Acknowledgements}

Authors (VVN, GMT \& MMS) are indebted to the Heads of the Botany Department of Dr. Babasaheb Ambedkar Marathwada University, Aurangabad (M.S.) and Savitribai Phule Pune University, Pune for providing facilities for research. Authors are grateful to the personnel of the following herbaria: BSI, CAL, DD, MH for consultation and E, GRA, K, OXF for their help in search of material marked by Lieut. Munro.

\section{Literature Cited}

Chandrabose, M. 1983. Malvaceae. In: Nair, N.C. \& A.N. Henry (eds.) Flora of Tamil Nadu, India. Series I: Analysis. Vol. 1. Botanical Survey of India, Coimbatore. pp. 31-37.

Chandrabose, M., Henry, A.N. \& N.C. Nair 1979. On the identity of Abutilon populifolium (Lamk.) Sweet and Abutilon neilgherrense Munro ex Wight. (Malvaceae). New Botanist, Int. Quart. J. Pl. Sci. Res. 4(3): 129.

Dunn, S.T. 1915. Malvaceae. In: Gamble J.S., (ed.), Flora of the Presidency of Madras, Adlard \& Son, London. pp. 86-102.

Mabberley, D.J. 2017. Mabberley's Plant-Book; A portable dictionary of plants, their classification and uses, Fourth Edition. Cambridge University Press, Cambridge. p. 1102.
Masters, M.T. 1874. Malvaceae. In: Hooker, J.D. (ed.), The Flora of British India. Vol. 1. L. Reeve \& Co., London. pp. 317-353.

Mohanan, M. \& A.V.N. Rao 2005. Malvaceae. In: Daniel, P. (ed.), The Flora of Kerala. Vol. 1. Botanical Survey of India, Kolkata. pp. 375-441.

Noltie, H. 2005. The Botany of Robert Wight. Regnum Veg. 145. A.R.G. Gantner Verlag Rugell, Liechtenstein.

Paul, T.K. 1993. Malvaceae. In: Sharma, B.D. \& M. Sanjappa (eds.), Flora of India. Vol. 3. Botanical Survey of India, Kolkata. pp.257-394.

Paul, T.K. \& M.P. Nayar 1988. Malvaceae. In: Nayar, M.P., Thothathri, K. \& M. Sanjappa (eds.), Fascicles of Flora of India. Fascicle 19. Botanical Survey of India, Kolkata. pp. 64-233.

Pullaiah, T. \& D.M. Rao 2002. Flora of Eastern Ghats: Hill Ranges of South East India. Vol. 1. Daya Publishing House, New Delhi. pp. 117-122.

Saldanha, C.J. \& S.R. Ramesh 1984. Malvaceae. In: Saldanha, C.J. (ed.), Flora of Karnataka. Vol. 1. Oxford \& IBH Publishing Co., New Delhi. pp. 241-263.

Sasidharan, N. 2004. Biodiversity Documentation for Kerala Part 6: Flowering Plants. Kerala Forest Research Institute, Peechi. pp. 47.

Sasidharan, N. 2013. A Digital database of flowering plants of Kerala Ver. 2. Kerala Forest Research Institute, Peechi.

Sivarajan, V.V. \& A.K. Pradeep 1996. Malvaceae of southern Peninsular India: A taxonomic monograph. Daya Publishing House, New Delhi. pp. 188-206.

Stafleu, F.A. \& R.S. Cowan 1981. Taxonomic Literature, Second Edition, Vol.3: Lh-O, Regnum Veg. 105. Bohn, Schletema \& Holkema, Utrecht \& dr. W. Junk b. v., Publishers, The Hague. pp. 660-661.

Turland, N.J., Wiersema, J.H., Barrie, F.R., Greuter, W., Hawksworth, D.L., Herendeen, P.S., Knapp, S., Kusber, W.H., Li, D.Z., Marhold, K., May, T.W., McNeill, J., Monro, A.M., Prado, J., Price, M.J. \& G.F. Smith 2018. International Code of Nomenclature for algae, fungi, and plants (Shenzhen Code) adopted by the Nineteenth International Botanical Congress Shenzhen, China, July 2017. Regnum Veg. 159. Koeltz Scientific Books, Königstein.

Wight, R. 1838. Illustrations of Indian Botany. Vol. 1(1-8). J.B. Pharoah, Madras. pp. 66.

Received: 13.04.2018

Revised and Accepted: 17.12.2018 